\title{
Research Paper: The Social Impacts of Dams on Rural Areas: A Case Study of Solaiman Shah Dam, Kermanshah, Iran
}

\author{
Afsaneh Malek Hosayni ${ }^{1}$, Ali Asghar Mirakzadeh ${ }^{2 *}$, Evagelos Lioutas ${ }^{3}$ \\ 1. MSc., Department of Promotion and Education of Agriculture, Faculty of Agriculture, Razi University, Kermanshah, Iran \\ 2. Assistant Professor, Department of Promotion and Education of Agriculture, Faculty of Agriculture, Razi University, Kermanshah, Iran. \\ 3. PhD, Department of Agricultural Economics, Faculty of Agriculture, Forestry and Natural Environment, Aristotle University of Thessaloniki, Thessaloniki, \\ Greece.
}

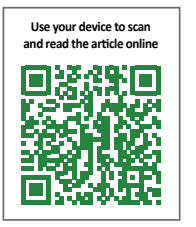

Citation: Malek Hosayni, A., Mirakzadeh, A. A., \& Lioutas E. (2017). The Social Impacts of Dams on Rural Areas: A Case Study of Solaiman Shah Dam, Kermanshah, Iran. Journal of Sustainable Rural Development, 1(2), 189-198. https://doi. org/10.29252/jsrd.01.02.189

doi: $:$ https://doi.org/10.29252/jsrd.01.02.189

\section{Article info:}

Received: 28 Mar. 2017

Accepted: 01 Jul. 2017
Keywords:

Rural development, Dam, Social impacts

\begin{abstract}
Purpose: This study aims to assess the social impacts of Solaiman Shah dam (Solaiman Shah, Kermanshah, Iran) on its surrounding villages using Social Impact Assessment tool.

Methods: This study follows a qualitative research design. In this regard, ten impacts and their important interrelations among them were categorized and evaluated.

Results: Our findings revealed that expansion of infrastructures and new opportunities for economic development have spread a feeling of prosperity, in other words the "promise-land effect," with positive reflections in the migration rates, social cohesion, and social capital. However, although the subjective well-being has been significantly improved for the majority of residents, the construction of dam was also followed by objecting voices, caused by unfair share of dam benefits which complicated the relations between neighboring villages, produced cultural disruption and obligatory resettlement of some peasants jeopardizing the social sustainability of the project.
\end{abstract}

Conclusion: Solaiman Shah dam has improved the economic situation of the region, enhanced subjective well-being, and facilitated new forms of cooperation among residents.

\section{Introduction}

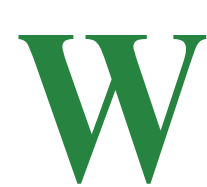

orldwide, policymakers encounter a complex set of challenges related to the desirability and appropriate implementation of developmental projects and their associated interventions. Particularly, in rural development projects, the implementation framework has to challenge with numerous problems hidden in the organization of local communities. Even though new rural development policies emphasize partnership and participation (Shortall and Warner, 2010), there is a considerable doubt as to whether the developmental projects are socially grounded. Many scholars (Esteves et al., 2012; Fazeli, 2010; Motiei Langroudi, 2003) note that the social, economic and natural aspects and externalities of developmental interventions are underestimated in many cases. Hence,

* Corresponding Author:

Ali Asghar Mirakzadeh, PhD

Address: Department of Promotion and Education of Agriculture, Faculty of Agriculture, Razi University, Kermanshah, Iran.

Tel: +98 (912) 6994511

E-mail: mirakzadeh@razi.ac.ir 
albeit ambitious, these projects often offer disappointing results, mainly due to the persistent focus on the economic dimension of rural development and overlooking ecological, cultural, and especially social consequences of these projects.

As a concept, rural development includes all types of improvement which can lead to the well-being of rural communities. However, a holistic approach to development is necessary during the evaluation phase of any development program. As Shortall (2004) underlines, the rural development process is mired by difficulties mainly caused of unrealistic expectations, inadequate definition of goals, and a lack of central government responsibility for the process. Moreover, the rural residents are often excluded from policy decisions about key determinants of their communities' development and well-being (Langille et al., 2008). Such exclusions could lead to unfavorable results, such as conflicts between local people and the government, social losses and violation of peoples' legal rights, whereas could also drive to the social discrimination (Fazeli, 2010).

Especially regarding the construction of dams, several paradigms confirm that such projects are sometimes accompanied by negative social impacts (Beck, Claassen, \& Hundt, 2012; Tilt, Braun, \& He, 2009; Srinivasan, 2001; Lerer \& Scudder, 1999). In this study, by using the Social Impacts Assessment (SIA), we investigated the social impacts of Solaimanshah's Dam (in the region of Kermanshah Province - Iran) in the rural area around the dam. The article is structured as follows. In the first section the need for assessments of social impacts that such projects induce and the principles of SIA are presented. Next, the methodological approach of the research is discussed. The presentation of the results follows, whereas the article ends with a concluding section summarizing the survey's key points.

\section{Literature Review}

\section{The need for a social impact assessment of dams}

The land use change that follows any large developmental projects, such as the construction of a dam, is inevitably accompanied by changes in the social life of local residents and the social structures of the communities affected by the project. Although each dweller is differently impacted by these changes (Williams \& Schirmer, 2012) the effects of such projects could be generally divided into seven sub-groups: health and social well-being impacts; liveability impacts; economic and material well-being impacts; cultural impacts; family and com- munity impacts; institutional, legal political and equity impacts; and gender relations impacts (Vanclay, 2003).

Assessment of these impacts facilitates the identification of the strengths and weaknesses of the projects and the development of strategies targeted at the maximization of strengths and the avoidance of weaknesses. Having its roots in the early 1970s, Social Impact Assesment (SIA) is the "the processes of analysing, monitoring and managing the intended and unintended social consequences, both positive and negative, of planned interventions" (Vanclay, 2003). From a relatively different standpoint, Freudenburg (1986) terms SIA as a procedure that "refers to assessing (as in measuring or summarizing) a broad range of impacts (or effects, or consequences) that are likely to be experienced by an equally broad range of social groups as a result of some course of action." Since the benefits and costs of any intervention are differentially distributed between and across the affected communities (Vanclay, 2012), using SIA could illuminate the impacts of a project in different population sub-groups.

Despite the problems associated with SIA, which concern legal and institutional constraints (Ahmadvand, Karami, Zamani, \& Vanclay, 2009), lack of consideration of the psychological impacts vis-à-vis the social impacts (Edelstein, 2003), lack of a fully elaborated and generally accepted typology (Becker, 2001) and the variety of methodological frameworks used, SIA remains a basic instrument for the imprinting of social echo of developmental interventions in many different fields (Esteves, Franks, \& Vanclay, 2012; Finsterbusch \& Wolf, 1981), since it allows decision makers to examine the projects' benefits and to test alternative interventions (Burdge \& Robertson, 1998; Carely \& Bustelo, 1984). Moreover, as Barrow (2010) explained, SIA is a toll that has the ability to identify and clarify the causes of conflicts regarding the environmental and natural resources management, whereas could possibly allow a more proactive management.

In the case of (large or small) dams, SIA contributes to a clearer understanding of the social issues that the construction of a dam puts at stake (Égré \& Senécal, 2003). SIA studies confirm that residents' queries are often in discrepancy with what policy makers believe as important. However, positive and negative impacts coexist in the affected regions (Brown, Tullos, Tilt, Magee, \& Wolf, 2009). Wyrick et al. (2009) stressed the environmental nuisance from these projects, while Lerer and Scudder (1999) emphasized on the health impacts. As regards the more "pure" social impacts, Tilt et al. (2009) noted that a dam's construction may result in changes in 

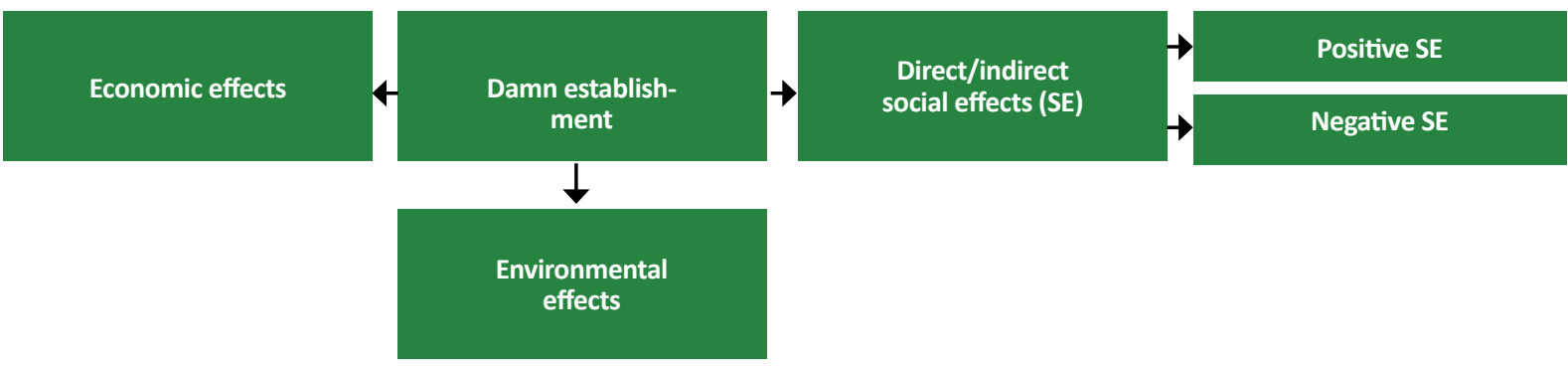

Figure 1. Conceptual framework of the study

the rural economy and employment structure, whereas also affects infrastructure and housing, non-material or cultural aspects of life and the migration and resettlement of people near the dam sites. In addition, the social networks, and their functions as well, may also be affected (Fuggle \& Smith, 2000). Figure 1 shows the study conceptual framework.

\section{Methodology}

We followed a qualitative approach to study the social impacts of Solaiman Shah dam construction on local people. Data were collected through personal interviews with all members of the local governance organization in the study area $(\mathrm{N}=48)$. A combination of the content analysis and thematic analysis was used to infer from the data. Method of the research was case study and respondents were selected by objective sampling (who was aware about dam situation and process) among 12 villages located in the downstream of the dam (Dashly
Bolagh, Solaiman Shah, Jobkabood Olya, Jobkabood Sofla, Nakhodab, Shorabad, Khanjarabad, Safaiye, Satar, Ghorveh, Ghias Abad, and Ghleye Hajiamin). All of these villages have been effected by dam project in various ways, especially with respect to their structure and economy (Figure 2). The farmers in these villages have experienced changes in their living conditions after dam construction. Data gathering continued to reach the data saturation. Data reliability and validity have been checked by member check and triangulation.

The study area, Solaiman Shah reservoir dam is located in Kermanshah Province, $102 \mathrm{~km}$ from Kermanshah City, $15 \mathrm{~km}$ from Sonqor City and $2 \mathrm{~km}$ from Soleyman Shah village on the Gavrood River, the main branch of the Sirvan River. The irrigation and drainage network of dam is also located in the west of the city of Sanqor between $47^{\circ} 27^{\prime}$ to $47^{\circ} 35^{\prime}$ E longitude and $34^{\circ} 45^{\prime}$ to $34^{\circ} 53^{\prime} \mathrm{N}$ latitude. Totally, 12 villages were located in the irrigation and drainage zone of the dam.

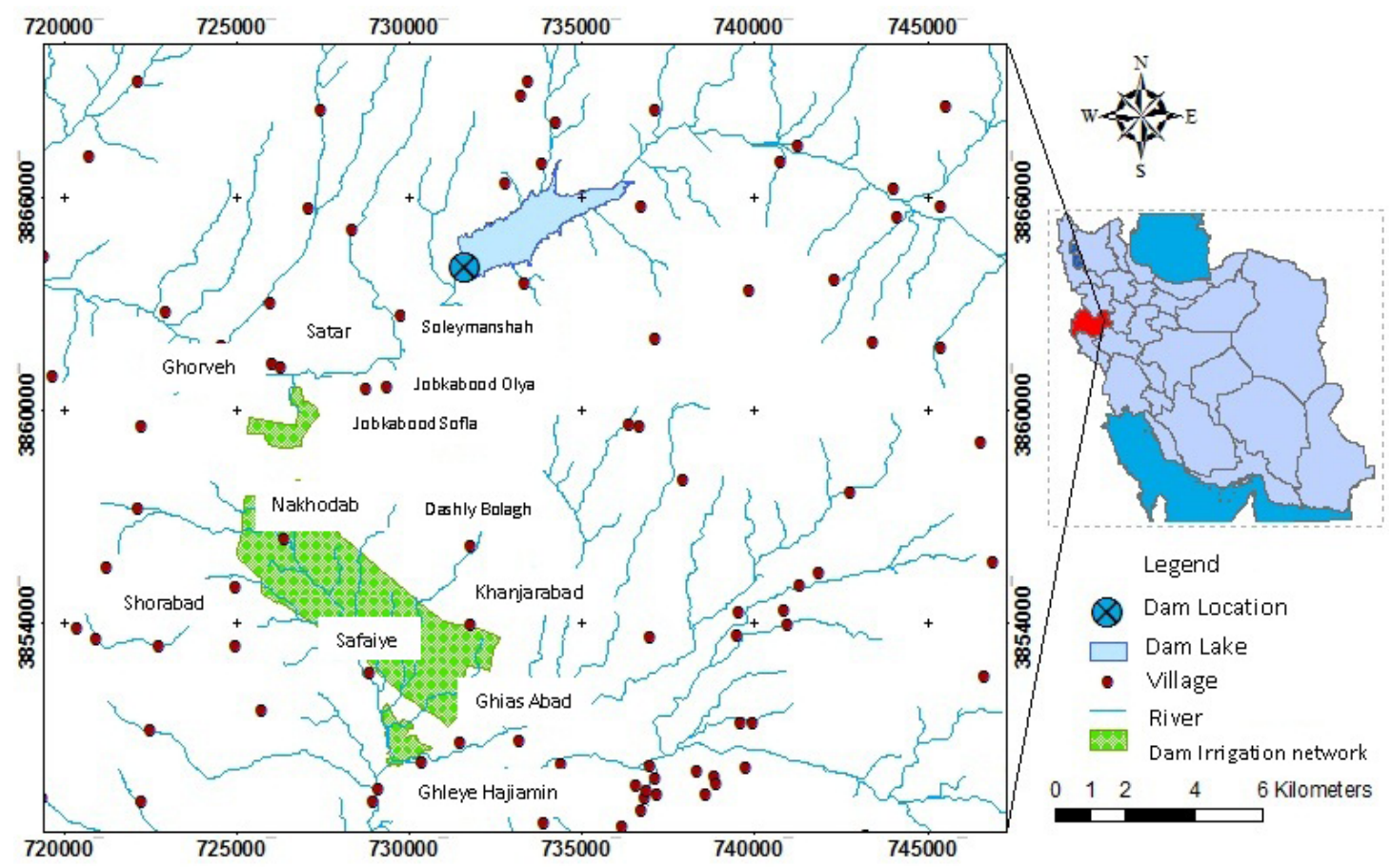

Figure 2. Solaiman Shad dam position in the study area (researchers, 2015) 
Given that SIA aims at identifying not only the social ramifications of the examined intervention but also - and mainly - the dynamics of the echo of these impacts, we attempted to categorize the intensity of the emerged social impacts. Although Rowan (2009) proposed a discrimination between magnitude and sensitivity, in our case study, we used a mixed approach in which the importance is characterized as "high" when the impact has very strong and positive or negative effects on the lives of a large group of people as well as other factors; "medium" when the affected people are few, the magnitude of the impact is moderate and other impacts are less dependent on it; and "low" in cases where the impact influences a small group of citizens in a small degree, and has limited - if any - reflections in the other social impacts.

\section{Findings}

After reviewing and conceptualizing the in-depth interviews, 10 main impacts were emerged that have affected villagers' way of living and their communities. Seven of them were positive impacts and the remaining 3 referred to negative impacts. Tables 1 and 2 illustrate the 10 categories of impacts and their dimensions as they were extracted from our analyses. Table 3 highlights the interrelations among the 7 positive impacts. These dimensions are presented and explained bellow.

\section{Expectation of a better future}

An important impact, often overlooked, is the expectation of a better life which, as interviewees stressed, has followed the construction of Solaiman Shah dam. According to our findings, local communities have experienced a flourishing period after the construction of dam, which has changed villagers' perspective about their region. The beauty of the landscape adds to this view. As one participant said: "villagers now view their region as a 'rose garden'."

In such a context, a general feeling of well-being exists, that facilitates both social relations and economic

Table 1. Positive social impacts

\begin{tabular}{|c|c|c|c|}
\hline Impact & Antecedents & Dimensions & Importance \\
\hline \multirow{3}{*}{$\begin{array}{l}\text { Opportunities for eco- } \\
\text { nomic development }\end{array}$} & Better production conditions & Higher agricultural income & High \\
\hline & Development of tourism in the region & Off-farm employment opportunities & High \\
\hline & $\begin{array}{l}\text { Development of alternative economic } \\
\text { networks }\end{array}$ & Expansion of the economic domain & Medium \\
\hline \multirow{3}{*}{ Poverty reduction } & $\begin{array}{c}\text { Creation of jobs during the construction } \\
\text { of dam }\end{array}$ & $\begin{array}{l}\text { Reduction of unemployment (tempo- } \\
\text { rary) }\end{array}$ & Low \\
\hline & $\begin{array}{l}\text { Creation of jobs after the construction } \\
\text { of dam }\end{array}$ & $\begin{array}{c}\text { Reduction of unemployment (long } \\
\text { term) }\end{array}$ & High \\
\hline & Increase in agricultural income & $\begin{array}{l}\text { Improvement of the economic status of } \\
\text { poor farmers }\end{array}$ & Medium \\
\hline \multirow{3}{*}{$\begin{array}{l}\text { Expectation of a better } \\
\text { future }\end{array}$} & The landscape became more beautiful & "Love for the region" & Low \\
\hline & General feeling of prosperity & $\begin{array}{l}\text { Facilitation of both social relations and } \\
\text { economic growth }\end{array}$ & High \\
\hline & Sense of "forthcoming well-being" & The "promise-land" effect & High \\
\hline \multirow{2}{*}{ Security } & Increase in the amount of water & Reduction of conflicts between farmers & Medium \\
\hline & Reduction of poverty & Reduction of crime rates & Medium \\
\hline \multirow{3}{*}{ Migration decrease } & Improved production conditions & $\begin{array}{c}\text { Renaissance of villagers' interest in } \\
\text { agriculture }\end{array}$ & High \\
\hline & Employment opportunities & Economical welfare & Medium \\
\hline & The "promise-land" effect & $\begin{array}{c}\text { Local people view their region through } \\
\text { a different optical corner }\end{array}$ & High \\
\hline \multirow{2}{*}{$\begin{array}{l}\text { Social cohesion and } \\
\text { social capital }\end{array}$} & Reduction of conflicts between farmers & $\begin{array}{l}\text { Improvement of social climate in the } \\
\text { area }\end{array}$ & Medium \\
\hline & Feeling of belonging to a community & Stronger ties between farmers & High \\
\hline $\begin{array}{l}\text { Expansion and improve- } \\
\text { ment of infrastructure }\end{array}$ & $\begin{array}{l}\text { Construction and improvement of the } \\
\text { road network }\end{array}$ & $\begin{array}{l}\text { Better utilization of the resources in } \\
\text { the area }\end{array}$ & High \\
\hline
\end{tabular}


Table 2. Negative social impacts

\begin{tabular}{|c|c|c|c|}
\hline Impact & Antecedents & Dimensions & Importance \\
\hline \multirow{2}{*}{$\begin{array}{l}\text { Imbalanced develop- } \\
\text { ment }\end{array}$} & Spatial factors & Unfair distribution of dam benefits & Medium \\
\hline & $\begin{array}{c}\text { Concentration of state attention in the } \\
\text { nearest villages }\end{array}$ & Regional polarization of development & Medium \\
\hline \multirow{2}{*}{$\begin{array}{l}\text { Violation of people's } \\
\text { rights }\end{array}$} & Compulsory expropriation & Property losses & High \\
\hline & Replacement by force & $\begin{array}{l}\text { Sudden (negative) changes in the social } \\
\text { and economic status for some locals }\end{array}$ & High \\
\hline \multirow{2}{*}{ Cultural disruption } & $\begin{array}{l}\text { Significant losses (homes, sources, em- } \\
\text { ployment) because of resettlement }\end{array}$ & Social dislocation & High \\
\hline & $\begin{array}{c}\text { Removal or destruction of basic cultural } \\
\text { benchmarks }\end{array}$ & $\begin{array}{l}\text { Inconvenience with the cultural value } \\
\text { system }\end{array}$ & Medium \\
\hline
\end{tabular}

growth. This general sense is not only related to the increase of local income per capita, but also has positively impacted the overall economic status in the region. Moreover, the development of some basic infrastructures has enhanced this feeling. However, the mentioned feeling of well-being, which is strongly associated with the satisfaction peasants feel about their lives, has ramifications in the long run for the region. In other words, the expectation for a better future creates the base for what could be termed as the "promise-land effect", i.e., the people perceive their land with ongoing development and prosperity.

\section{Opportunities for economic development}

In spite of the well-documented increase of agricultural income, according to the respondents, a significant change that followed the construction of Solaiman shah dam was the generation of new employment opportunities.

During the construction of the dam, many local workers were occupied in different fields giving a tonic effect in the local economy. However, most importantly, the nonagricultural economic activity gained momentum after dam construction, mainly due to the development of tourism in the region. In addition, alternative employment opportunities such as hose works have also emerged in the region, contributing thus to a significant reduction of unemployment and expansion of the economic domain.

\section{Poverty reduction}

In line with the previous impact (opportunities for economic development), the reduction of poverty after the construction of the dam was reported by a considerable percentage of our participants. Poverty reduction has been achieved through two major effects. The first concerns the growth of agricultural income - as a consequence of the improved production conditions - which revived the economic life in the region. The second effect refers to the development of alternative economic activities and the reduction of unemployment

\section{Security}

According to our findings, improvement of economic status of rural people and reduction of conflicts between peasants have become a basis for a sense of security in the villages around the dam. Interviewees noted that incidents of violation over properties have almost eliminated in the region. On the other hand, the reduction of unemployment and the reduction of poverty, in general, have mitigated social conflicts and crime rates, so that the activity of "Dasak" (a local term used to describe local persons that cooperate with thieves) has almost ceased.

\section{Migration decrease}

As a rural area that depends on and influenced by the prosperity of agriculture, the region near the dam has become a more attractive place for local people. The new and improved production conditions that emerged as a result of more irrigation water have led to a renaissance of villagers' interest in agriculture. This, in turn, has served as a major source of motivation for local people to stay in the villages. This situation is summarized in the following quote: "Settlement in a village depends on agriculture which depends on water, so the water from the dam keeps the residents in the villages."

In line with the expectation of a better future, an important impact of dam construction concerns the reduction 
of migration to nearby towns. Since our study has not revealed any particular policy targeted at the reduction of migration, this one could be attributed to the perceived personal and community's benefits from the dam. As the majority of the respondents mentioned, the flourishing of farming after the construction of dam has resulted in a significant change in villagers' mindset: the region has turned into a promising place, where people want to stay and develop economic and social activities.

On the other hand, new opportunities for tourism development at the regional level have also affected the migration from the study area. Despite the direct impact of the new tourism opportunities (generation of off-farm income), the attraction of tourists has also changed the way villagers view their region, reinforcing thus their motive to live in the area.

\section{Expansion and improvement of infrastructure}

One of the most tangible impacts of the dam was the construction and/or improvement of the road network. Parts of the provincial and rural roads have been repaired and asphalted. Thus, the accessibility of the region has been significantly improved. The transportation from and to urban centers became easier, while at the same time, the access of tourists to the region has been significantly facilitated.

This, in turn, on the one hand facilitates farmers and other rural residents to invest in non-farm activities which generate additional employment and income for the rural households, while on the other hand permits the better utilization of the resources in the area, given that the transportation of products to the urban centers is now faster and more convenient.

\section{Social cohesion and social capital}

According to respondents, a significant change in the social life within the study area concerns the concepts of social cohesion and social capital as well. All participants agreed that before construction of dam the conflicts between villagers were common. Such incidents have now reduced, as the construction of dam adequately covers the irrigation needs of farmers. Moreover, individuals who worked together during the construction of dam had the opportunity to know each other, thus establishing better social relationships.

On the other hand, belonging to a community with shared resources and values has increased social cohesion in the study area. As the interviewees stressed, vil- lagers cooperate easily, trust each other more, and thus common ventures are more successful. These new forms of collective actions are based on their pursuit to achieve mutual benefits. For example, people from neighboring lands cooperate in the creation of irrigation channels. This framework is conducive to the enhancement of social capital among villagers. The ties between farmers have become stronger, facilitating the development of behaviors that surpass the individual level and increase cohesion and solidarity within the rural communities.

\section{Imbalanced development}

Respondents indicate an imbalanced share of dam benefits among the villages due to spatial factors such as their distances from the dam. Villages near the dam enjoy the bulk of the returns in terms of water amount available for their crops, but also as regards the compensation allowances and the tourism growth. Thus they have better opportunities to offset declines in traditional forms of economic activities. Consequently, the gains from the dam are distributed unfair among the villages, with the more distal ones benefit the least.

This injustice has reflections in the relations between neighboring villages while, on the other hand, make difficult for the distant villages to compete for public investments. In other words, the development is concentrated in certain core areas, which in turn receive more state attention thus the potential to press for investments.

\section{Cultural disruption}

A negative effect the dam caused in the area relates to the removal or destruction of some basic cultural benchmarks (replacement of tombs in a village or of a mosque in another case). Because these cultural assets are part of a local heritage that is difficult to be replaced; some residents of the villages who have been affected in this manner have developed a negative attitude towards the dam and its impacts. Thus, the balance between positive and negative impacts from the construction of dam may be quite different for them.

\section{Violation of people's rights}

Our analyses confirmed that the construction of dam has caused the justifiable grievances for some rural residents. In two villages (Ghalah Geogh, Ghomam), due to expropriation, some farmers have lost their houses, their jobs, and their land, However according to respondents, the payment of compensation allowances was not on time or the countervailing benefits were insufficiently small. 
This parameter indicates that the construction of dam has affected differently local people and that a "two-gear" development exists: some locals have only benefited by the project whereas others have significant losses becoming vulnerable to social dislocation. This casts doubts over the social sustainability in the region, and complicate the social relations between the local communities.

\section{Discussion}

The main purpose of this study was to identify the social impacts followed the construction of Solaiman Shah dam. Our analysis revealed ten categories of social impacts that influenced the local residents caused by dam construction. Seven of these categories affect the local societies in a positive way. Although SIA usually studies separately each one of the positive effects, in this research we attempted to disclose the salient interrelations among them (Table 3). Our findings indicate the existence of bidirectional relationships among the emerged social impacts.

Consistent with previous studies, our results indicate that poverty reduction and the higher rates of agricultural and non-agricultural income are significant positive social impacts. However, one of the most important parameters, yet underrepresented in the relevant literature, was the expectation of a better future. Rooted in the economic development of the region, the abovemen- tioned psychological factor serves as a central thrust for the creation of a sense of contemporary prosperity and a feeling of "forthcoming well-being." On the other hand, the feeling that the region develops on a sustainable path generates the "promise-land effect", which exerts a positive influence in the migration rates in the region. Moreover, the expansion of infrastructure fostered economic activity, added more to this feeling.

As Argyle and Martin (1991) argued, subjective wellbeing could be conceptualized as "a person's satisfaction with life", which according to Abbott and Wallace (2012), is positively affected by the economic growth. Despite its subjective nature, this general sense strengthens locals" "love for the region", whereas facilitates social relations, which according to Degli Antoni (2009), could have positive reflections in individuals' welfare. Thus, the prevalent feeling of prosperity and optimism is the starting point of a cycle, that affects the other social impacts, and on the other hand is affected by all other factors. Research on psychology has proven that income affects positively life satisfaction (Guven \& Sørensen, 2011; Boes \& Winkelmann, 2009), especially for the lowest classes of population (Graham, 2004). However, social capital (Sarracino, 2013; Bjørnskov, 2003; Brehm \& Rahn, 1997) and social cohesion (Helliwell \& Putnam, 2004) also evoke a feeling of well-being. Finally, this feeling provides a suitable background for improve-

Table 3. Interrelations among positive social impacts

\begin{tabular}{|c|c|c|c|c|c|c|c|}
\hline \multirow[b]{2}{*}{ Social Impacts } & \multicolumn{7}{|c|}{ Social Impacts } \\
\hline & $\begin{array}{l}\text { Expecta- } \\
\text { tion of } \\
\text { a Better } \\
\text { Future }\end{array}$ & Security & $\begin{array}{c}\text { Expansion } \\
\text { and Improve- } \\
\text { ment of Infra- } \\
\text { structure }\end{array}$ & $\begin{array}{l}\text { Migration } \\
\text { Decrease }\end{array}$ & $\begin{array}{l}\text { Opportu- } \\
\text { nities for } \\
\text { Economic De- } \\
\text { velopment }\end{array}$ & $\begin{array}{l}\text { Poverty } \\
\text { Reduc- } \\
\text { tion }\end{array}$ & $\begin{array}{c}\text { Social } \\
\text { Cohesion } \\
\text { and Social } \\
\text { Capital }\end{array}$ \\
\hline $\begin{array}{l}\text { Expectation of a bet- } \\
\text { ter future }\end{array}$ & & + & n.i. & ++ & + & + & ++ \\
\hline Security & + & & n.i. & + & n.i. & n.i. & + \\
\hline $\begin{array}{l}\text { Expansion and } \\
\text { improvement of } \\
\text { infrastructure }\end{array}$ & ++ & + & & + & ++ & + & n.i. \\
\hline Migration decrease & + & n.i. & n.i. & & + & n.i. & ++ \\
\hline $\begin{array}{l}\text { Opportunities for } \\
\text { economic develop- } \\
\text { ment }\end{array}$ & ++ & n.i. & n.i. & ++ & & ++ & ++ \\
\hline Poverty reduction & ++ & ++ & n.i. & ++ & + & & + \\
\hline $\begin{array}{l}\text { Social cohesion and } \\
\text { social capital }\end{array}$ & + & ++ & n.i. & + & + & + & \\
\hline
\end{tabular}

+: Positive impact, ++: Very positive impact, n.i.: No impact. 
ment of the economic and social status in the region, feeding back the cycle.

However, the uneven distribution of benefits and gains among villagers results in different opportunities for economic development and consequently different incomes, which impaired the social equilibrium. As a number of studies (Burdia, 2012; Senik, 2009; Clark, Frijters, \& Shields, 2008) indicate, the subjective well-being is affected not only by the actual income but also - and more intensively - by the relative income. In other words, the perception of individuals about their economic status is a cofunction of the income of societal peers or other persons that have similar characteristics (Senik, 2002). Because our research proved that the economic benefits of the dam are unevenly distributed among villages - with the more distant villages to enjoy significantly less economic power - and among individuals as well; differences in relative income negatively affect locals' subjective well-being.

In this regard, a more direct and significant impact that influences villagers' lives refers to the violation of some people's rights. In two villages (Ghalah Geogh, Ghomam) peasants were forced to abandon their homes due to the compulsory expropriation whereas compensations were insufficient, leading some of the residents in the impoverishment. Other studies (Tilt et al., 2009; Lee, 2003; Lerer \& Scudder, 1999) also indicate that involuntary resettlement has remained one of the most serious outcomes of dam construction projects. As Rowan (2009) suggests, this outcome affects more poor families, because "they have fewer resources to anticipate, cope with, resist, and recover from such impacts." Moreover, another parameter, despite its lower importance, that exerts a strong influence on populations adhered to and affected by cultural or religious values is the cultural disruption, related to the removal or destruction of cultural benchmarks.

Our analysis confirmed that Solaiman Shah dam has improved the economic situation of the region, enhanced subjective well-being, and facilitated new forms of cooperation among residents. In this context, both social capital and cohesion have been significantly empowered. On the other hand, our findings revealed some major shortcomings. First, the involuntary resettlement has not been accompanied with a corresponding countervailing and/or relieving measures (proper amount of compensations, employment posts for peasants who lost their land). Second, this "two-gear" development raises questions about the social sustainability of the project. Third, the focus of political attention has been mainly directed to some villages (those located near to the dam) creating a new stratification among villages.
In spite of our study limitation (its data were collected only from the members of local government as well as overlooking the health impacts within our framework), it contributes to the relevant literature by uncovering a latent but important impact, namely the expectation of a better future which increases subjective well-being, and by illuminating the important interrelations among social impacts of large dams construction.

\section{Acknowledgements}

This research did not receive any specific grant from funding agencies in the public, commercial, or not-forprofit sectors. This research did not receive any specific grant from funding agencies in the public, commercial, or not-for-profit sectors.

\section{Conflict of Interest}

The authors declared no conflicts of interest.

\section{References}

Abbott, P., \& Wallace, C. (2012). Rising Economic Prosperity and Social Quality the Case of New Member States of the European Union. Social Indicators Research, 115(1), 419-439. doi: $10.1007 / \mathrm{s} 11205-012-9992-0$

Ahmadvand, M., Karami, E., Zamani, G. H., \& Vanclay, F. (2009). Evaluating the use of Social Impact Assessment in the context of agricultural development projects in Iran. Environmental Impact Assessment Review, 29(6), 399-407. doi: 10.1016/j. eiar.2009.03.002

Argyle, M. \& Martin, L. (1991). The origins of happiness. In F. Strack, M. Argyle, \& N. Schwarz, (Eds.), Subjective Well-Being (pp. 77-104). Oxford: Pergamon.

Barrow, C. J. (2010). How is environmental conflict addressed by SIA? Environmental Impact Assessment Review, 30(5), 293-301. doi: 10.1016/ j.eiar.2010.04.001

Beck, M. W., Claassen, A. H., \& Hundt, P. J. (2012). Environmental and livelihood impacts of dams: common lessons across development gradients that challenge sustainability. International Journal of River Basin Management, 10(1), 73-92. doi: 10.1080/15715124.2012.656133

Becker, H. A. (2001). Social impact assessment. European Journal of Operational Research, 128(2), 311-321. doi: 10.1016/s03772217(00)00074-6

Bjornskov, C. (2003). The Happy Few: Cross-Country Evidence on Social Capital and Life Satisfaction. Kyklos, 56(1), 3-16. doi: 10.1111/1467-6435.00207

Boes, S., \& Winkelmann, R. (2009). The effect of income on general life satisfaction and dissatisfaction. Social Indicators Research, 95(1), 111-128. doi: 10.1007/s11205-009-9452-7 
Brehm, J., \& Rahn, W. (1997). Individual-Level Evidence for the Causes and Consequences of Social Capital. American Journal of Political Science, 41(3), 999. doi: 10.2307/2111684

Brown, P. H., Tullos, D., Tilt, B., Magee, D., \& Wolf, A. T. (2009). Modeling the costs and benefits of dam construction from a multidisciplinary perspective. Journal of Environmental Management, 90, S303-S311. doi: 10.1016/j.jenvman.2008.07.025

Burdge, R. J. \& Robertson, R. A. (1998). Social Impact Assessment and the Public Involvement Process. In Burdge, R. J. (Ed.), A Conceptual Approach to Social Impact Assessment (pp: 183-192). Middleton, Wisconsin: Social Ecology Press.

Budria, S. (2012). Are Relative-Income Effects Constant Across the Well-Being Distribution? Journal of Happiness Studies, 14(4), 1379-1408. doi: 10.1007/s10902-012-9384-9

Carley, M. J. \& Bustelo, E. S. (1984). Social impact assessment and monitoring: A guide to the literature. Abingdom: Routledge.

Clark, A. E., Frijters, P., \& Shields, M. A. (2008). Relative Income, Happiness, and Utility: An explanation for the Easterlin paradox and other puzzles. Journal of Economic Literature, 46(1), 95-144. doi: 10.1257/jel.46.1.95

Degli Antoni, G. (2009). Does satisfaction matter? A microeconomic empirical analysis of the effect of social relations on economic welfare. Journal of Socio-Economics, 38(2), 301-309. doi: 10.1016/j.socec.2008.07.001

Edelstein, M. R. (2003). Weight and weightlessness: administrative court efforts to weigh psycho-social impacts of proposed environmentally hazardous facilities. Impact Assessment and Project Appraisal, 21(3), 195-203. doi: 10.3152/147154603781766257

Égré, D., \& Senécal, P. (2003). Social impact assessments of large dams throughout the world: lessons learned over two decades. Impact Assessment and Project Appraisal, 21(3), 215-224. doi: $10.3152 / 147154603781766310$

Esteves, A. M., Franks, D., \& Vanclay, F. (2012). Social impact assessment: the state of the art. Impact Assessment and Project Appraisal, 30(1), 34-42. doi: 10.1080/14615517.2012.660356

Fazeli, M. (2010). [Assessment of social impacts (Persian)]. Tehran: Jame'e Shenasan.

Finsterbusch, K. \& Wolf C. P. (1981). Methodology of social impact assessment. $2^{\text {nd }}$ Edition. Stroudsburg, PA: Hutchinson Ross.

Freudenburg, W. (1986). Social impact assessment. Annual Review of Sociology, 12(1), 451-478. doi: 10.1146/annurev. soc.12.1.451

Fuggle, R., \& Smith, W. (2000). Large dams in water and energy resource development in the people's Republic of China. World Commission on Dams Country Review Paper. Cape Town: World Commission on Dams.

Graham, C. (2004). Can happiness research contribute to development economics? Washington D.C.: Brookings Institution.

Guven, C., \& Sørensen, B. E. (2011). Subjective well-being: keeping up with the perception of the Joneses. Social Indicators Research, 109(3), 439-469. doi: 10.1007/s11205-011-9910-x

Helliwell, J. F., \& Putnam, R. D. (2004). The social context of wellbeing. Philosophical Transactions of the Royal Society B: Biological Sciences, 359(1449), 1435-1446. doi: 10.1098/rstb.2004.1522
Langille, L., Munro, I., Romanow, P., Lyons, R., Bull, A. \& Williams, P. (2008). Building collaborative capacity for research and influencing policy: the rural communities impacting policy project. Journal of Rural and Community Development, $3(3), 23-55$

Lee, K. C. (2003). Enhancing collaborative governance for natural area management: Some experiences from Taiwan. International Planning Studies, 8(1), 35-51. doi: $10.1080 / 13563470320000059237$

Lerer, L. B., \& Scudder, T. (1999). Health impacts of large dams. Environmental Impact Assessment Review, 19(2), 113-123. doi: 10.1016/s0195-9255(98)00041-9

Motiei Langroudi, H, (2003) [Rural planning with emphasis on Iran (Persian)]. First Edition. Mashhad: Jahad-e Daneshgahi.

Rowan, M. (2009). Refining the attribution of significance in social impact assessment. Impact Assessment and Project Appraisal, 27(3), 185-191. doi: 10.3152/146155109x467588

Sarracino, F. (2013). Determinants of subjective well-being in high and low income countries: Do happiness equations differ across countries? The Journal of Socio-Economics, 42, 51-66. doi: 10.1016/j.socec.2012.11.006

Senik, C. (2002). When information dominates comparison: Learning from Russian subjective panel data. Journal of Public Economics, 88(9-10), 2099-2123. doi: 10.2139/ssrn.328180

Senik, C. (2009). Direct evidence on income comparisons and their welfare effects. Journal of Economic Behavior \& Organization, 72(1), 408-424. doi: 10.1016/j.jebo.2009.04.019

Shortall, S. (2004). Social or Economic Goals, Civic Inclusion or Exclusion? An Analysis of Rural Development Theory and Practice. Sociologia Ruralis, 44(1), 109-123. doi: 10.1111/j.14679523.2004.00265.x

Shortall, S., \& Warner, M. E. (2010). Social inclusion or market competitiveness? a comparison of rural development policies in the European Union and the United States. Social Policy \& Administration, 44(5), 575-597. doi: 10.1111/j.14679515.2010.00730.x

Srinivasan, B. (2001). Social impacts of large dams: Gender, equity and distribution issues. Economic and Political Weekly, 36(43): 4108-4114.

Tilt, B., Braun, Y., \& He, D. (2009). Social impacts of large dam projects: A comparison of international case studies and implications for best practice. Journal of Environmental Management, 90, S249-S257. doi: 10.1016/j.jenvman.2008.07.030

Vanclay, F. (2002). Conceptualising social impacts. Environmental Impact Assessment Review, 22(3), 183-211. doi: 10.1016/ s0195-9255(01)00105-6

Vanclay, F. (2012). The potential application of social impact assessment in integrated coastal zone management. Ocean \& Coastal Management, 68, 149-156. doi: 10.1016/j.ocecoaman.2012.05.016

Vanclay, F. (2003). International Principles for Social Impact Assessment: their evolution. Impact Assessment and Project Appraisal, 21(1), 3-4. doi: 10.3152/147154603781766464

Williams, K. J. H., \& Schirmer, J. (2012). Understanding the relationship between social change and its impacts: The experience of rural land use change in south-eastern Aus- 
tralia. Journal of Rural Studies, 28(4), 538-548. doi: 10.1016/j. jrurstud.2012.05.002

Wyrick, J. R., Rischman, B. A., Burke, C. A., McGee, C., \& Williams, C. (2009). Using hydraulic modeling to address social impacts of small dam removals in southern New Jersey. Journal of Environmental Management, 90, S270-S278. doi: 10.1016/j.jenvman.2008.07.027 